\title{
EVALUATION OF IMPACT OF COVER MATERIALS ON REDUCTION OF WATER EROSION OF SOIL IN VINEYARDS
}

\author{
Patrik Burg $^{1}$, Vladimir Masan ${ }^{1}$, Alice Cizkova ${ }^{1}$, Vladimir Visacki ${ }^{2}$ \\ ${ }^{1}$ Mendel University in Brno, Czech Republic; ${ }^{2}$ University of Novi Sad, Serbia \\ patrik.burg@mendelu.cz, vladimir.visacki@polj.uns.ac.rs
}

\begin{abstract}
Water erosion is becoming one of the most serious problems in the global scale. It causes soil degradation and damage and reduces capacity of soil production. This paper work discusses and evaluates the results of the impact of several types of cover materials on soil erosion in vineyards in the Czech Republic. The experiment was based on four variants, where three types of cover materials were selected for the protection against soil erosion: grain straw (var. A, consumption of covering material was $1,200 \mathrm{~g} \cdot \mathrm{m}^{-2}$ ), wood chips (var. B, consumption of cover material was $4,000 \mathrm{~g} \cdot \mathrm{m}^{-2}$ ) and compost (var. D, consumption of cover material was 2,000 $\mathrm{g} \cdot \mathrm{m}^{-2}$ ). The fourth control variant $(\mathrm{C})$ consisted of a cultivated interlayer without cover material. During the measurements, the soil was picked up by pockets specifically created and modified for retaining loose soil with the possibility of free flowing of remaining water. The conclusive results of the evaluation indicate the positive effect of the cover materials on the protection of soil erosion even when affecting the soil moisture. From the evaluated variants no trace was recorded using a grain straw cover. Moreover, the highest soil moisture content, during the whole vegetation, was also found when using this. When using wood chips, the value of erosive wash during the observed period was $1 \mathrm{~g} \cdot \mathrm{m}^{-2}$, when using compost, the value was $8 \mathrm{~g} \cdot \mathrm{m}^{-2}$. The results showed that the highest soil pitch $15 \mathrm{~g} \cdot \mathrm{m}^{-2}$ occurred, when the control variant without the use of cover material was applied. The use of cover materials can therefore be considered as a promising way of soil protection from water erosion. The experiments which have been carried out suggest, from the viticulture practice point of view, that the availability and price of individual cover materials, including the cost of their application, will play a significant role in the application of these anti-erosion measures.
\end{abstract}

Keywords: water erosion, covering materials, straw, wood chips, compost.

\section{Introduction}

Soil is an easily destroyable but hardly renewable natural resource [1]. It has been identified that one centimetre of soil layer is formed approximately between 80 and 150 years. This layer can be destroyed in a few minutes due to erosion, which is unfortunately currently common place on many grounds [2]. This is due to the frequent absence of systematic protection of land against erosion that would limit land losses to permissible levels. In the Czech Republic, more than $50 \%$ of farmed land is threatened by water erosion and the number is still growing [3].

While the issue of soil erosion on land used for plant production is subject to much attention and several papers are being published on this issue, sufficient information with regards to the soil erosion within the vineyards in the conditions of the Czech Republic is missing. The focus of the research is rather on the issue of planting grass between the interchanges [4]. Also, Badalíková and Hrubý, Cerdan et al., Lieskovsky and Kenderessy [5-7], they all similarly state that under the EU conditions, vineyards on sloping land represent the most endangered part of the farmed land.

The initial experimental measurements carried out in viticulture-developed countries (e.g., Germany and Austria) indicate that the use of suitable mulching materials [8] is a very good precautionary measure to prevent the threat of erosion on slopes. In the Czech Republic, the issue of soil erosion protection of agricultural land was discussed in the works of, e.g., Javurek and Šimon [9] and Janeček et al. [10].

The results of their work show that a crucial factor for preventing or mitigating water erosion is not to leave the surface of the soil without protective cover. Soil cover, with plant residues or mulch, plays a key role in soil erosion control. Various methods are used to evaluate soil erosion. According to Javurek et al. [11], the greatest influence on water erosion has the slope and the length of the land on the slope line, the vegetation cover, the soil characteristics and its vulnerability to erosion, the presence of anti-erosion measures and the frequency of torrential rain.

The aim of this paper is to verify the different types of cover (mulch) materials to reduce soil pitch in the vineyard interconnection. 


\section{Materials and methods \\ Experiment area}

For experimental measurements a test site was selected. This is located in the "Velke Pavlovice" wine-growing sub region, in the area of "Rakvice" and on the track/land called "Kozí Horky". The site is in a corn production area, a very warm and dry climate region with an altitude of 164 metres above sea level. The land has a flat surface. The average annual temperature in 2016 was $11.4{ }^{\circ} \mathrm{C}$ and a total rainfall was approximately $540 \mathrm{~mm}$. The soils are classified as a pelican black lands on very heavy substrates (clays, marshes and tertiary sediments), on a scale from heavy to very heavy with a lighter horizon, rarely gravely, with a tendency of moisture on the surface in the profile. Skimmer is classified from none up to $10 \%$. The slope of the land is up to $10 \%$.

\section{Character of the mulching materials and experiment variants}

The experiment was based on 4 variants, for which 3 kinds of cover material were chosen for the soil protection - crushed grain straw (variant A, consumption of covering material $1,200 \mathrm{~g} \cdot \mathrm{m}^{-2}$, volume weight $100 \mathrm{~kg} \cdot \mathrm{m}^{-3}$ ), wood chips (variant $\mathrm{B}$, consumption of cover material $4,000 \mathrm{~g} \cdot \mathrm{m}^{-2}$, volume weight $400 \mathrm{~kg} \cdot \mathrm{m}^{-3}$ ) and compost composed from grape pomace, grass, wood chips and vegetable waste (variant $D$, consumption of covering material $2,000 \mathrm{~g} \cdot \mathrm{m}^{-2}$, volume weight $560 \mathrm{~kg} \cdot \mathrm{m}$ $\left.{ }^{3}\right)$. The fourth control variant (C) consisted of a cultivated interlayer without covering material.

\section{Measuring of the meteorological data and soil moisture}

A weather station was installed in the experimental vineyard, which recorded data on air temperature, soil temperature, rainfall and soil moisture at a depth in between 0.1 and $0.3 \mathrm{~m}$. In all experimental variants, the soil moisture values were measured by "VIRRIB" humidity meters, located at a depth in between 0.1 and $0.3 \mathrm{~m}$. The soil humidity was recorded during the vegetation every day at regular fifteen-minute intervals using the "VIRRIBLOGGER" recording unit.

\section{Evaluation of the soil erosion}

The erosion of soil was detected by special pockets created for retaining loose soil with free flow of water. The width of each pocket was 1 meter, the length was 0.5 meter, the back part of the pocket was 0.3-meter-high with sloping sides. The length of the monitored slope was approximately 100-meter and 1-meter width. Each pocket was made of polyethylene with flow holes in the back of the pocket. Inside the pocket, a nonwoven, dense cloth was inserted, which captures the soil slides and the leachate water flows through the holes in the rear. The captured content of sediments is collected, dried, weighed and re-calculated to the amount of uneven soil of 1 ha. When removing the loose soil, a soil moisture sample is taken before drying the sludge itself. The weight of the fabric is deducted from the weight of the soil. The content of the soil is determined by the content of the nutrients, the $\mathrm{pH}$ and the humus content.

\section{Analytical methods}

The experiment started on April 1, 2017 and since this date the soil was continually monitored. The initial physical state of the soil was determined by using "Kopecky physical cylinders", soil humidity gravimetrically [12], humus content (Novák methodology) and soil reaction (Melich III method). The soil was analysed for the content of basic nutrients, humus and soil reaction according to the "Methodology of the Central Institute for Surveying and Testing in Agriculture" and compared with the soil analyses carried out at the beginning of the growing season.

\section{Statistical analysis}

A statistical analysis was performed using the software package "Statistics 12.0" (StatSoft Inc., Tulsa, Oklahoma, USA). Analysis of variance was conducted, and the results were compared using the Tukey's multiple range assay at a significance level $\alpha=0.05$.

\section{Results and discussion}

At the beginning of vegetation, soil humidity was evaluated on the experimental site. It was between 18.78 and $24.21 \%$ humidity at individual depths of the soil profile $(0.1-0.3 \mathrm{~m})$. The average value was $21.35 \%$ humidity. Table 1 shows the results of the physical character of soil samples taken. The nutrient content in soil at the beginning of vegetation is shown in Table 2. 
The physical character of soil

\begin{tabular}{|c|c|c|c|c|c|c|}
\hline \multirow{3}{*}{$\begin{array}{l}\text { The depth } \\
\text { of soil, } m\end{array}$} & \multirow{3}{*}{$\begin{array}{c}\text { Density, } \\
\mathrm{g} \cdot \mathrm{cm}^{-3}\end{array}$} & \multirow{3}{*}{$\begin{array}{c}\text { Porosity, } \\
\%\end{array}$} & \multicolumn{2}{|c|}{ Content } & \multirow{2}{*}{$\begin{array}{c}\text { Maximum } \\
\text { capillary } \\
\text { capacity }\end{array}$} & \multirow{2}{*}{$\begin{array}{l}\text { Minimal } \\
\text { air capacity }\end{array}$} \\
\hline & & & Water & Air & & \\
\hline & & & \multicolumn{2}{|c|}{$\%$ content } & \multicolumn{2}{|c|}{$\%$ content } \\
\hline $0-0.1$ & 1.05 & 59.95 & 25.40 & 34.55 & 45.91 & 14.04 \\
\hline $0.1-0.2$ & 1.23 & 53.23 & 26.47 & 26.76 & 37.48 & 15.75 \\
\hline $0.2-0.3$ & 1.29 & 50.95 & 24.13 & 26.83 & 36.99 & 13.96 \\
\hline Average & 1.19 & 54.71 & 25.33 & 29.38 & 40.13 & 14.58 \\
\hline
\end{tabular}

The results of chemical analysis of soils at measured variants

Table 2

\begin{tabular}{|c|c|c|c|c|c|c|c|c|}
\hline \multirow{2}{*}{$\begin{array}{l}\text { The depth } \\
\text { of soil, } m\end{array}$} & \multicolumn{4}{|c|}{$\mathbf{m g} \cdot \mathrm{kg}^{-1}$} & \multirow{2}{*}{$\begin{array}{l}\mathbf{N}_{\mathrm{c}}, \\
\%\end{array}$} & \multirow{2}{*}{$\underset{\%}{\text { Humus, }}$} & \multirow{2}{*}{$\mathrm{pH}_{\mathrm{KCl}}$} & \multirow{2}{*}{$\begin{array}{c}\text { HK / } \\
\text { FK }\end{array}$} \\
\hline & $\mathbf{K}-\mathbf{p}$ & $M g-p$ & $\mathbf{P}-\mathbf{p}$ & $\mathrm{Ca}-\mathbf{p}$ & & & & \\
\hline $0-0.1$ & 410 & 448 & 44 & 4,569 & 0.23 & 3.51 & 7.40 & 0.93 \\
\hline $0.1-0.2$ & 476 & 469 & 38 & 4,890 & 0.24 & 3.50 & 7.40 & 0.97 \\
\hline $0.2-0.3$ & 501 & 490 & 46 & 5,111 & 0.21 & 3.47 & 7.40 & 0.96 \\
\hline Average & 462.33 & 469.00 & 42.67 & $4,856.67$ & 0.23 & 3.49 & 7.40 & 0.95 \\
\hline
\end{tabular}

The values given in Figure 1 show that the highest soil moisture was found throughout the vegetation in the soil covered with grain straw. The average value for this trial variant was $26.54 \%$ over the time of the monitored period. For other experimental variants, the values ranged from $22.74 \%$ by volume (control), $21.96 \%$ by volume (chips) and $21.66 \%$ by volume (compost). For example, Hlušek et al. [4] state that a sufficiently thick layer of grain straw mulch on the soil surface prevents evaporation of water and thus contributes to maintaining higher soil moisture. A somewhat different effect was achieved in the experimental variants covered with wood chips and the compost, so the cover layers of dark colour. Filipovic et al. [13] state that dark matter absorbs more heat than light, with higher turbidity than increasing vapour and decreasing soil moisture. The positive influence on the long-term soil moisture values showed in these experimental variants has manifested only at the rainfalls over $10 \mathrm{~mm}$.

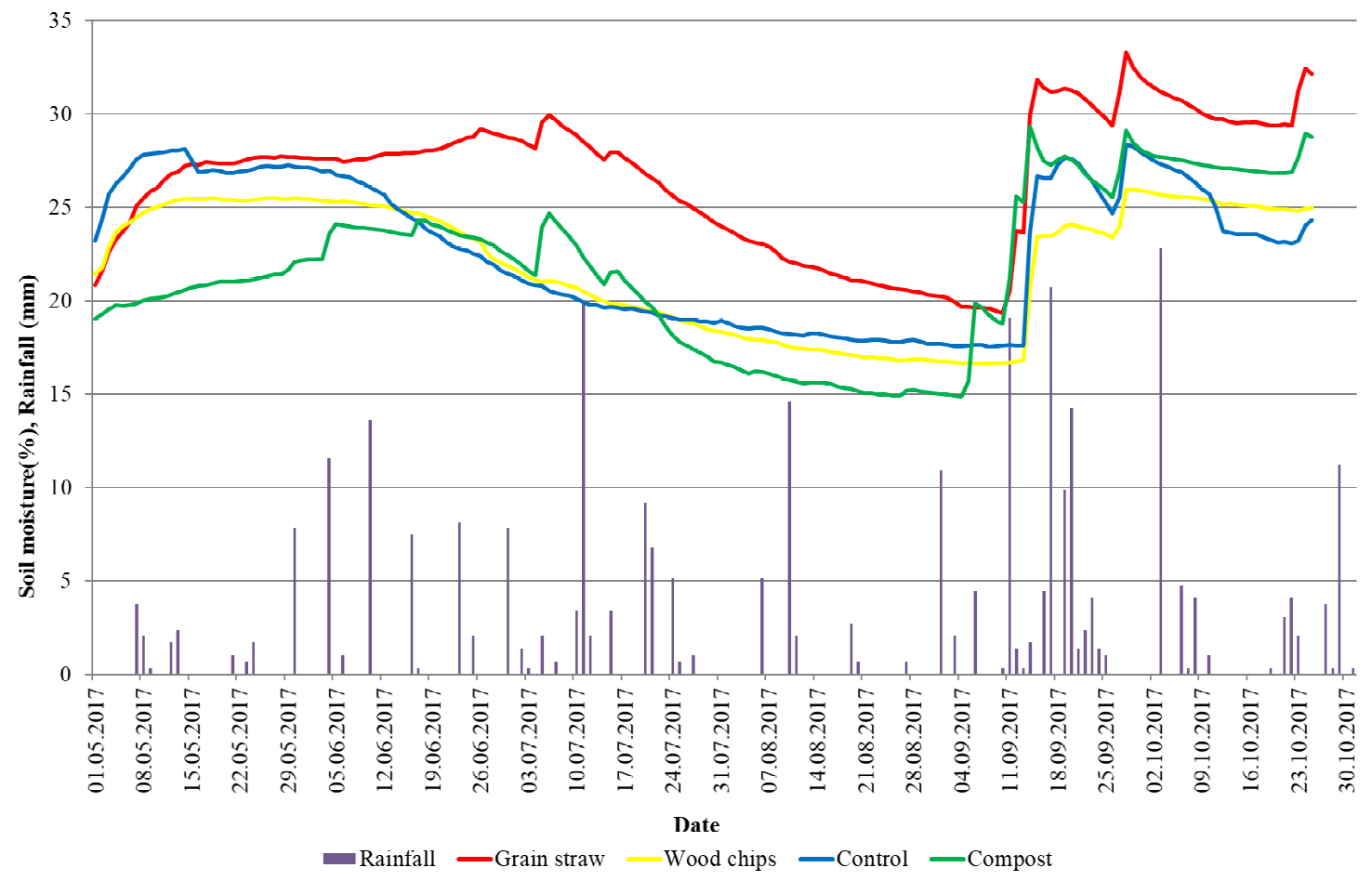

Fig. 1. Value of soil moisture and rainfalls 
In overall, during the vegetation period from May to August, it was measured under-average rainfalls in the amount of $160 \mathrm{~mm}$, the average temperature during the vegetation was $18.3^{\circ} \mathrm{C}$. Therefore, soil erosion was recorded only three times as shown in Table 3. Initial tracking suggests that no trace was recorded for variant A of all the variants evaluated, but only a small amount of skew was noted for variant $\mathrm{B}$, with wood chips covering material. The highest shear values were recorded for control variant $C$, without the use of cover material. The evaluated soil loss was $15 \mathrm{~g} \cdot \mathrm{m}^{-2}$. The obtained values were statistically evaluated by the variance analysis and the Tukey's multiple range test at a significant level $\alpha=0.05$, as shown in Table 3 .

Table 3

The soil erosion - the evaluation of variants

\begin{tabular}{|c|c|c|c|c|c|}
\hline \multirow{2}{*}{$\begin{array}{c}\text { Experiment } \\
\text { variants }\end{array}$} & \multicolumn{2}{|c|}{ Date and amount of the erosion, $\mathbf{g} \cdot \mathbf{m}^{-2}$} & \multicolumn{2}{c|}{ Scale of erosion, $\mathbf{g} \cdot \mathbf{m}^{-2}$} \\
\cline { 2 - 6 } & $\mathbf{1 0 . 0 6 . 2 0 1 7}$ & $\mathbf{1 1 . 0 7 . 2 0 1 7}$ & $\mathbf{1 0 . 0 8 . 2 0 1 7}$ & Average & Amount \\
\hline A (grain straw) & $0.01 \pm 0.00^{\mathrm{a}}$ & $0.01 \pm 0.00^{\mathrm{a}}$ & $0.01 \pm 0.00^{\mathrm{a}}$ & $0.01^{ \pm} 0.00^{\mathrm{a}}$ & 0.03 \\
\hline $\mathrm{B}$ (wood chips) & $0.01 \pm 0.00^{\mathrm{a}}$ & $1.00 \pm 0.15^{\mathrm{a}}$ & $0.01 \pm 0.00^{\mathrm{a}}$ & $0.34 \pm 0.51^{\mathrm{a}}$ & 1.02 \\
\hline C (control) & $2.01 \pm 0.06^{\mathrm{b}}$ & $6.99 \pm 1.41^{\mathrm{b}}$ & $6.00 \pm 0.40^{\mathrm{b}}$ & $5.01 \pm 2.45^{\mathrm{b}}$ & 15.00 \\
\hline $\mathrm{D}$ (compost) & $0.01 \pm 0.00^{\mathrm{a}}$ & $4.98 \pm 0.87^{\mathrm{b}}$ & $3.02 \pm 0.24^{\mathrm{b}}$ & $2.67 \pm 2.27^{\mathrm{ab}}$ & 8.01 \\
\hline
\end{tabular}

* Data are expressed as means \pm standard deviation, different letters in the same columns represent significant difference $(P<0.05)$.

From the values shown in Table 3, a clear positive effect of grain straw and wood chips on soil degradation is evident, when compared to the control variant without cover material. This condition has been confirmed for all terms in which leakage was measured. Nearing and Bradford (1985) [14] found that the disturbing force caused by rain that leads to soil surface damage is largely due to the height of the surface runoff and the amount of retained water. Biddoccu et al. [15] state that mulching the soil in vineyards and orchards is to provide a covering layer with a thickness of up to $200 \mathrm{~mm}$. The mulch layer significantly reduces erosion, reduces or eliminates the need for cultivation, reduces evaporation and increases the water intake.

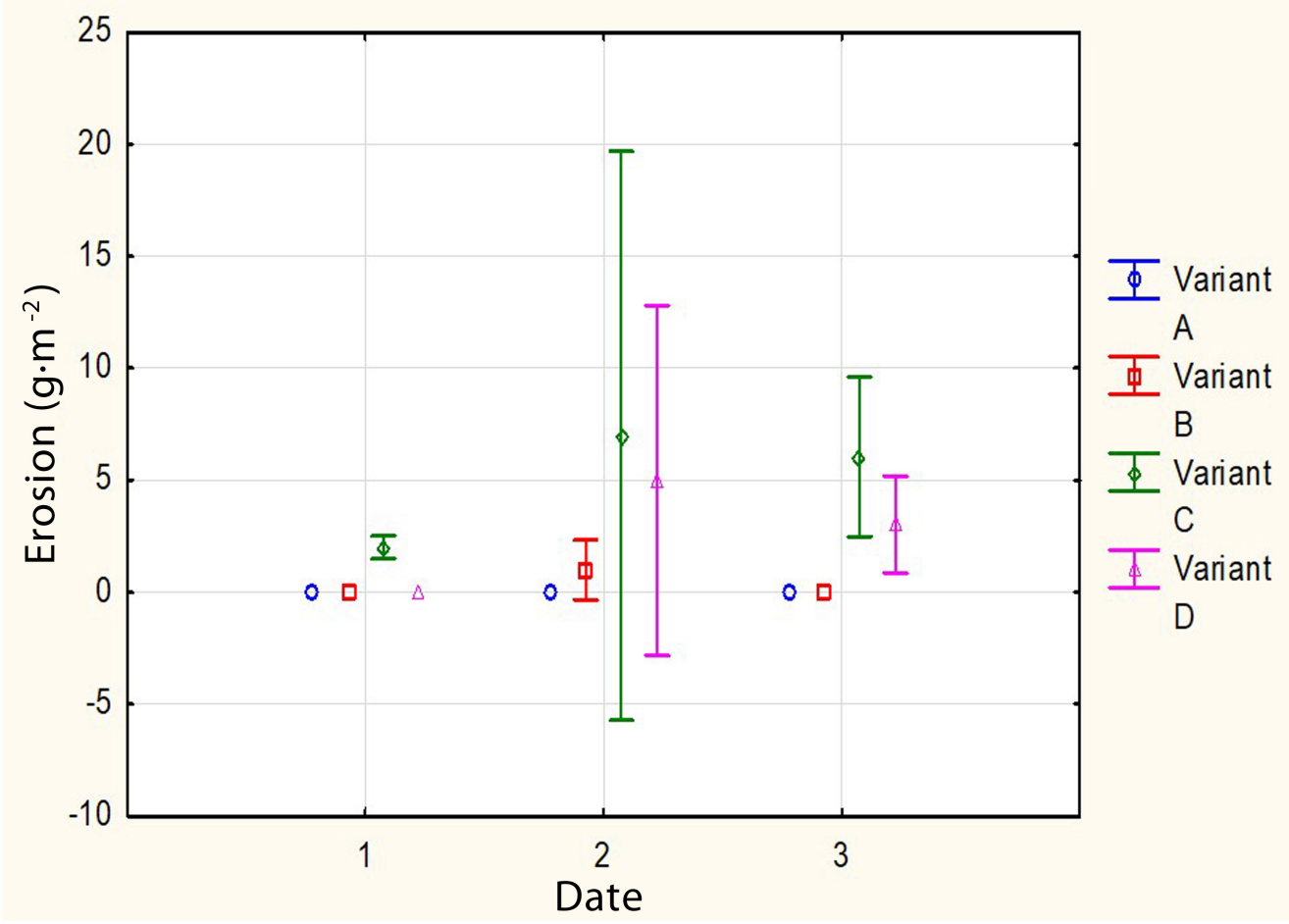

* Vertical columns indicate $95 \%$ confidence intervals.

Fig. 2. Comparison of soil erosion at evaluated variants

At the same time, while the soil erosion was occurring, there was also a loss of nutrients that were washed away along with loose soils. Table 4 shows the average values of chemical analyses of soil loosening in the evaluated variants. 
The observed values show a significant loss of nutrients and humus from the soil due to soil erosion. Badalíková and Bartlová [16] state that the nutrient loss is due to the relative amount of nutrient accumulation in the sample of the soil, which is then reflected in the conversion to the given unit.

Table 4

Average values of the chemical analyses of the loose soils (2017)

\begin{tabular}{|c|c|c|c|c|c|c|c|}
\hline \multirow{2}{*}{$\begin{array}{c}\text { Experiment } \\
\text { variants }\end{array}$} & \multicolumn{4}{|c|}{$\mathbf{m g} \cdot \mathbf{k g}^{-1}$} & \multirow{2}{*}{$\begin{array}{c}\mathrm{N}_{\mathrm{c}}, \\
\%\end{array}$} & \multirow{2}{*}{$\begin{array}{c}\text { Humus, } \\
\%\end{array}$} & \multirow{2}{*}{$\mathbf{p H}_{\mathrm{KC}}$} \\
\hline & $\mathbf{K}-\mathbf{p}$ & Mg - p & $\mathbf{P}-\mathbf{p}$ & $\mathbf{C a}-\mathbf{p}$ & & & \\
\hline $\begin{array}{l}\text { A (grain } \\
\text { straw) }\end{array}$ & $393 \pm 2.52^{\mathrm{a}}$ & $401 \pm 3.51^{\mathrm{a}}$ & $65 \pm 2.08^{\mathrm{a}}$ & $4.761 \pm 0.15^{\mathrm{a}}$ & 0.16 & 2.84 & 7.3 \\
\hline $\begin{array}{c}\text { B (wood } \\
\text { chips) }\end{array}$ & $405 \pm 3.51^{\mathrm{b}}$ & $430 \pm 2.52^{\mathrm{b}}$ & $59 \pm 2.31^{c}$ & $4.840 \pm 0.03^{\mathrm{a}}$ & 0.14 & 2.70 & 7.3 \\
\hline $\mathrm{C}$ (control) & $431 \pm 3.51^{\mathrm{d}}$ & $481 \pm 4.16^{\mathrm{d}}$ & $71 \pm 2.00^{b}$ & $4.820 \pm 0.09^{\mathrm{a}}$ & 0.20 & 3.5 & 7.4 \\
\hline $\mathrm{D}$ (compost) & $422 \pm 3.79^{c}$ & $460 \pm 3.06^{\mathrm{c}}$ & $67 \pm 0.58^{\mathrm{ab}}$ & $4.860 \pm 0.01^{\mathrm{a}}$ & 0.21 & 3.2 & 7.3 \\
\hline
\end{tabular}

* Data are expressed as means \pm standard deviation, different letters in the same columns represent significant difference $(P<0.05)$.

Table 4 shows that the highest amount of nutrients in potassium and magnesium is statistically significant in the control variant and in the variant covered with compost. The amount of loose potassium is primarily influenced by soil properties. Apart from sorption of potassium on the surface of soil colloids, potassium is able, thanks to its small hydration coating, to enter into the crystalline clay minerals, where it is fixed. Likewise, magnesium, due to the large moisture coating, is weaker bounded in the soil. The amount of magnesium leaching is related to the soil content and climatic factors, in particular by the distribution of precipitation and temperatures during the year [1].

A number of authors have focused in their work on the issue of minimizing soil erosion in the vineyard interconnection, especially by combining the vegetation cover and appropriate soil treatment with cultivation tools [17-19]. The results of these works confirm the positive effect of all anti-erosive agro-environmental measures in the protection of soils in the interconnection of vineyards. Blavet et al. [17] observed the highest soil loss due to erosion in herbicide-treated vineyards, less in the cultivated vineyards and the lowest values for grasses with grassland, or the vineyards covered with soil by the plant mulch. A fairly serious problem, however, remains the competition of plant cover and vine shrubs for water and nutrients. For example, Marques et al. [20] point to the disadvantages of grassed grazing in arid areas, which are manifested by reduced soil infiltration capacity, water scarcity for shrub growth, including reduced grape yields. Badalíková and Bartlová [16] report that the amount of soil erosion depends not only on soil surface protection and on the way it is processed, but on the physical, chemical and biological properties of the soil, from which the infiltration capacity of the soil develops.

\section{Conclusions}

1. The experimental evaluations were focused on the issue of soil erosion in the interconnection of vineyards in 2017, in the Czech Republic, in the town area of "Rakvice". The experiment was carried out in four variants using different types of cover materials - grain straw $\left(1,200 \mathrm{~g} \cdot \mathrm{m}^{-2}\right)$, wood chips $\left(4,000 \mathrm{~g} \cdot \mathrm{m}^{-2}\right)$ and compost $\left(\right.$ dose $\left.2,000 \mathrm{~g} \cdot \mathrm{m}^{-2}\right)$. The fourth control variant consisted of a cultivated interlayer without cover material.

2. The results of statistical analyses of measured data relating to soil erosion confirm the positive effect of cover materials in their counter-erosion protection. Out of all evaluated variants, the lowest soil erosion was when using a grain straw cover layer $\left(0.03 \mathrm{~g} \cdot \mathrm{m}^{-2}\right)$. When wood chips were used, the values of soil erosion during the measured period were $1.02 \mathrm{~g} . \mathrm{m}^{-2}$, and when using a compost, the values were $8.1 \mathrm{~g} \cdot \mathrm{m}^{-2}$. The results showed that the highest soil pitch $\left(15.0 \mathrm{~g} \cdot \mathrm{m}^{-2}\right)$ occurred in the control variant without the use of cover material.

3. Together with the soil erosion, the humidity of soil was measured as well. This was measured by the "VIRRIB" humidity meters located at a depth of 0.1-0.3 $\mathrm{m}$. The highest average of the soil moisture was found during the whole vegetation in the soil covered with grain straw $(26.54 \%$ by 
volume), followed by a control variant ( $22.74 \%$ by volume), wood chips ( $21.96 \%)$ and compost ( $21.66 \%$ by volume).

4. The use of cover materials can be considered as a promising way of protecting the soil against water erosion and, at the same time, as a measure for increasing the soil moisture. However, from the viticulture practice point of view, the availability and price of individual cover materials, including the cost of their application, will play a significant role in the application of these antierosion measures.

\section{Acknowledgements}

This paper was supported by the project CZ.02.1.01/0.0/0.0/16_017/0002334 Research Infrastructure for Young Scientists, this is co-financed from Operational Programme Research, Development and Education.

\section{References}

[1] Jandák J., Prax A., Pokorný E. Půdoznalství (Soil science). Brno: Mendelova zemědělská a lesnická univerzita v Brně, 2007. 142 p. (In Czech).

[2] Hubbard R.K., Hagrove W.L., Lowrance R.R., Williams R.G. Physical properties of a coastal plain soil as affected by tillage. Soil Water Cons, vol. 49, 1994, pp. 276-283.

[3] Javůrek M., Vach M. Effect of cover crops in conservation soil tillage systems. Proceedings of Agro the XIth ESA Congress, 2010, Montpellier, France, pp. 241-242.

[4] Hlušek J., Baroň M., Burg P. etc. Réva vinná (Grapevine). Praha: Profi Press, 2015. 151 p. (In Czech).

[5] Badalíková B., Hrubý J. Hodnocení výběru meziplodin z hlediska požadavků na ochranu půdy (Evaluation of the selection of catch crops for soil protection requirements). Acta fytotechnica et zootechnica, vol. 11, 2008, pp. 49-52. (In Czech).

[6] Cerdan O., Govers G., Le Bissonnais Y. etc. Rates and spatial variations of soil erosion in Europe: A study based on erosion plot data. Geomorphology, vol. 122, 2010, 167-177.

[7] Lieskovský J., Kenderessy P. Modelling the effect of vegetation cover and different tillage. Practices on soil erosion in vineyards: a case study in Vráble (Slovakia) using watem/sedem. Land Degradation \& Development, vol. 25, 2014, pp. 288-296.

[8] Hausener Y. Bodenerosion in Weinbergen (Soil erosion in vineyards). Final Report. Trier: Univesitaet Trier, 2014. 23 p. (In German).

[9] Javůrek M., Šimon J. Možnosti využití mulče (The possibility of using mulch). Farmář, vol. 6, 2005, 31-33. (In Czech).

[10] Janeček M., Kubátová E., Tippl M. Revise Determination of the Rainfall-runoff Erosivity Factor $\mathrm{R}$ for Application of USLE in the Czech Republic. Soil \& Water Research, vol. 2, 2006, pp. 65-71.

[11] Javůrek M., Hůla J., Vach M. etc. Impact of different soil tillage technologies on soil erosion effect mitigation. Scientia Agriculturae Bohemica, vol. 39, 2008, pp. 218-223.

[12] Jandák J. Cvičení z půdoznalství (Seminar of soil science). Brno: Mendelova zemědělská a lesnická univerzita v Brně, 2003. 92 p. (In Czech).

[13] Filipović V., Romić D., A Romić M. etc. Plastic mulch and nitrogen fertigation in growing vegetables modify soil temperature, water and nitrate dynamics: Experimental results and a modeling study. Agricultural Water Management, vol. 176, 2016, pp. 100-110.

[14] Nearing M.A., Bradford J.M. Single Waterdrop Splash Detachment and Mechanical Properties of Soils. Soil Science Society of America Journal, vol. 49, 1985, pp. 547-552.

[15] Biddoccu M., Ferraris S., Opsi F., Cavallo E. Long-term monitoring of soil management effects on runoff and soil erosion in sloping vineyards in Alto Monferrato (North-West Italy). Soil and Tillage Research, vol. 155, 2016, pp. 176-189.

[16] Badalíková B., Bartlová J. Influence of incorporated organic matter on soil and infiltration. In Soil - School. Gödöllö, Hungary: Szent Istvan University Press on behalf of Márta Birkás, 2012, pp. 293-298. 
[17]Blavet D., De Noni G., Le Bissonnais Y. etc. Effect of land use and management on the early stages of soil water erosion in French Mediterranean vineyards. Soil and Tillage Research, vol. 106, 2009, pp. 124-136.

[18]Ramos M.C., Martínez-Casasnovas J.A. Effects of field reorganization and spatial variability of runoff and erosion rates in vineyards of northeastern Spain. Land Degradation \& Development, vol. 21, 2010, pp. 1-12.

[19] Novara A., Gristina L., Saladino S.S. etc A. Soil erosion assessment on tillage and alternative soil managements in Sicilian vineyards. Soil and Tillage Research, vol. 117, 2011, pp. 140-147.

[20] Marques M.J., García-Muñoz S., Muñoz-Organero G., Bienes R. Soil conservation beneath grass cover in hillside vineyards under Mediterranean Climatic conditions (Madrid, Spain). Land Degradation \& Development, vol. 17, 2010, pp. 122-131. 